\title{
Access and Use of Electronic Information Resources Among Medical Students in University of Port Harcourt Library
}

\author{
Boma T. David-West ${ }^{1}$ Ph.D, CLN Patience O. Ekpang ${ }^{2}$ Ph.D \\ 1. Department of Library and Information Science, University of Port Harcourt, Rivers State, Nigeria \\ 2. University of Calabar Library Cross Rivers State, Nigeria.
}

\begin{abstract} formulated to guide the study. will boost their retrieval skills.

Keywords: access, information, resources, electronic, utilization

DOI: $10.7176 / \mathrm{IKM} / 9-4-08$

Publication date: April $30^{\text {th }} 2019$
\end{abstract}

This paper investigated access and use of electronic information resources among medical students in University of Port Harcourt Library. The study adopted a correlational survey research design. Questionnaire was used as instruments for data collection. The population of the study was made up of all the medical students in University of Port Harcourt, Rivers State, totaling five hundred and forty two (542), and one hundred and eight(108) were selected as sample and used for the study, three research questions and three hypotheses were

Mean and standard deviation were used to analyze the data collected. The null hypotheses formulated was rejected suggesting that there is significant relationship between Access and Use of Electronic Information Resources among medical students in University of Port Harcourt. The study revealed that most of the medical students lack the ability to access and use these electronic information resources. The study recommends trainings and orientation for students on the use and access of relevant electronic information resources which

\section{Introduction}

Libraries and information centres play valuable roles in meeting societal information needs, facilitating and making access to such information possible. According to (Ogunsola 2011) access to right information at the right time gives people greater control over their destiny. The ability to access information is very vital for the utilization of electronic resources in libraries. The ability to access electronic information resources enables a researcher to select the appropriate terminology that express the concept or subject under investigation. This has to do with knowledge of the structure of the database.

The establishment of the electronic library oversees that electronic information resources are available online to meet users need for research (Wu et al 2016). The result of this initiative has increased electronic information content adding thousands of information resources contributing to the widening of knowledge at the disposal of the library. Libraries now provide statistical tools for data analysis along with training and various online support systems for students to enjoy access to witnessing exponential growth and diversity, best described by (Smith 2016) as retooling library information resources to support the innovation of reshaping library practices.

Al-Adwan et al (2013) stated that although many universities across the world have incorporated internet-based learning systems, the success of their implementation requires an extensive understanding of end user acceptance process. The growth supply of literature in libraries that is available in digital format facilitates effective searching of materials needed by students. There are indications that students ways of accessing literature for their work has changed in electronic information environment. The students requires knowing how to clearly define a subject or an area of investigation, formulate a search strategy that takes into consideration different sources of information and the variables that information is organized, analyze the data collected for value, relevance, suitability. Students should have the ability to access electronic information resources, via search engines, subject gateways, web directories and other web based resources. Hence students should be familiar with the collections of the electronic library so as to access the right website relevant to their study.

The academic libraries has a major role to play, which is to provide access to knowledge. It is important that students formulate a clear focused and interesting academic problem that is researchable. One major role in research and decision making related to learning activities is information and knowledge. Therefore, access to and use of appropriate and up-to-date information and knowledge by students is vital if they are to carry out their activities successfully. 
Accessing of electronic information resources is very vital to the end user. Resources may be available in the library but the user may not be able to access them. One may identify citations in indexes, but may not have access to their sources containing the relevant articles. The more accessible electronic information resources are, the more likely they are to be used. Readers sometimes tend to use electronic information resources that require the least effort to access. Mohammed(2013) states that there should be various tools and education on how to access electronic information resources. In accessing electronic information resources,(Amuso 2012) encourages libraries to embark on selective dissemination of information (SDI) as this will advertise and market the available resources and services to those in need. Studies have revealed that some library users are adopting electronic habits and making increasing use of the new electronic resources that comprises computer, internet, intranet etc to utilize resources in digital media.

Generally, electronic information resources may be used for academic and for general purpose. Thus library users are placing new demand on their libraries. They require access to the latest information resources.

Access and use of electronic information resources by research scholars therefore, is an important area of study in today's information environment. It has become important in academic institution as it plays a pivotal role in meeting the information and users' needs of the institution. A global effort is on the way to access and use e-resources in academic libraries. Studies revealed that students know very little about how to access and use electronic information resources. Hence this study was designed to fill the gap.

\subsection{Objective of the Study}

- To determine the level of awareness

- To also establish the extent of access and use of electronic information resources by students

- To identify problems inhibiting access and use of electronic information resources.

\subsection{Research Questions}

1. What is the relationship between students' access ability and utilization of electronic information resources?

2. What is the relationship between students' level of awareness and use of electronic information resources?

3. What is the relationship between students' challenges in accessing and use of electronic information resources?

\subsection{Hypotheses}

1. There is no significant relationship between students' access ability and use of electronic information resources in University of Port Harcourt.

2. There is no significant relationship between student's level of awareness and use of electronic information resources in University of Port Harcourt.

3. There is no significant relationship between students' challenges in accessing and use of electronic information resources.

\subsection{Statement of Problem}

The relevance of library is the accessibility of its resources. The new trend in the library is the use of technology in delivering library services. This enables users to have access to vast electronic information resources to enhance their research. Students are to benefit from these electronic information resources. Unfortunately due to various factors like poor funding, power failure, inability to make use of the computer systems, some students are not even aware of these resources thereby leading to inability to access these resources. It has been observed that medical studentsare least oriented on access, adoption ad use of these electronic information resources services in the library. Despite the effort of the library management in putting up these resources for use. The researcher observed that access, and use of electronic information resources by medical students is very low.

It is on this premise that this study was designed to investigate the access and use of electronic information resources among medical students in University of Port Harcourt.

\subsection{Literature Review}

Adembo and Olatundum (2017) examined a study on accessibility and use of web based database on health internet work access to research initiative (HINARI) portal by physicians. The study revealed that $60 \%$ of 
physicians access the portal once every two weeks. However respondents are faced with the challenges of inability to access due to inadequate retrieval skills. The study recommended the training and retraining of physicians in the use of HINARI portal so as to justify the huge amount of effort and money spent by World Health Organization to make the resources freely available to scientist in developing countries.

Moreso, Lefuma(2017) opined that strategies should be in place to improve access and use of eresources, as well as library orientation programs. These will help to familiarize the medical students on how to make use of these resources.

Shushma, (2015) state that student lack skills in accessing e-resources. There should be an improvement in the access of facilities with high internet subscription to more e-resources in the university library. Also Boakye (2016) examined a study on the awareness, accessibility and utilization of scholarly electronic journals. The study revealed low awareness and accessibility levels as well as under utilization of scholarly electronic journals.

Aina (2011) stated that accessibility determines the speed at which an information in any format is obtained. The ability to access information from electronic resources enhances students' learning, as the resources provide teachers and students with vast quantities of information in an easily accessible non-sequential format. Ukachi (2014) asserts that students should possess adequate information literacy skills on the use of electronic resources.

Okello and Majara (2008) opined that access is very critical in this age because without access, information is worthless. Habib, Enite and Aworo (2015) states that lack of search skills, inability to access and power outage, were some of the challenges faced by staff in Nigerian libraries. That is to say for easy accessibility students must have the ability to access electronic resources for the completion of their course work.

According to Ugah (2008) opined that availability of information does not assure its accessibility. This implies that the more accessible information sources are the more likely they are used. Walker and Keenan (2015) distinguished between available experiences including creating audio, tutorials, collaborating with these users in the acquisition process and developing relevant accessibility services.

Johnson et al (2012) refers to access as applied delivery, instructions, methods with e-resources ensuring proper technological software, hardware and internet connections as well as providing user instruction on how to use these materials effectively. Uriel (2016) opined that library should adopt technology major information resources. This will enable the library enjoy online information such as online open access catalogue and online database. Okonjo (2016) states that the major challenge faced when accessing and utilizing electronic information is lack of awareness, training and poor infrastructure. Unfortunately, there is lack of awareness in developing countries especially with respect to e-resources services.

Abubakar and Ahmed (2013). There should be information access tools appropriately set out for students to enable them access information. Jaegar (2007) argues that there can be no exchange user collection or management of information. The various libraries should assist the users with different search tools to enable them access and retrieve information with ease. Most of the studies revealed that the available resources have been under-utilized. This means that users do not know how to access them and also do not know what the resources offer. The ability to access information is very important for the utilization of electronic library resources.

\subsection{Methodology}

The correlational survey design was adopted for this study. The population of the study consisted of all medical students in the University of Port Harcourt totaling five hundred and forty two (542). The simple random sampling techniques was used for the study. A sample of (108) one hundred and eight was drawn from the population. A structured questionnaire tagged Access and Use of Electronic Information Resources among Medical Students in University of Port Harcourt (AUEIRMS) was developed and used in collecting data for the study. The instrument was duly validated using face and content validity. A total of 108 copies of the instrument was distributed to the study participants by the researcher and three trained research assistants. At the end, 102 copies of the questionnaire were retrieved and used for the data analysis, representing $94.4 \%$ return rate. The research questions were answered using the mean and standard deviation while the hypotheses was tested using the Z-test at 0.05 level of significance. 


\section{Result}

Research Question One: What is the relationship between students' accessibility and utilization of electronic information resources?

Table 1: Correlation results indicating relationship between students accessibility and utilization of electronic information resources.

\begin{tabular}{|c|c|c|c|c|c|c|c|}
\hline Variable & & $\mathrm{N}$ & $\sum x^{2}$ & $\sum y^{2}$ & $\sum X Y$ & $\mathrm{r}$ & Result \\
\hline $\begin{array}{l}\text { Students accessibility of } \\
\text { utilization of e-resources }\end{array}$ & e-resources & 102 & 30.15 & 29.79 & 29.90 & 0.87 & $\begin{array}{l}\text { Positive } \\
\text { relationship }\end{array}$ \\
\hline
\end{tabular}

Calculated coefficient of 0.87 represents positive correlation between students accessibility ad utilization of electronic information resources. This result therefore affirmed positive relationship between understudied variables.

Research Question Two: What is the relationship between students' level of awareness and use of electronic information resources?

Table 2: Correlation results indicating between users' level of awareness and use of electronic information resources.

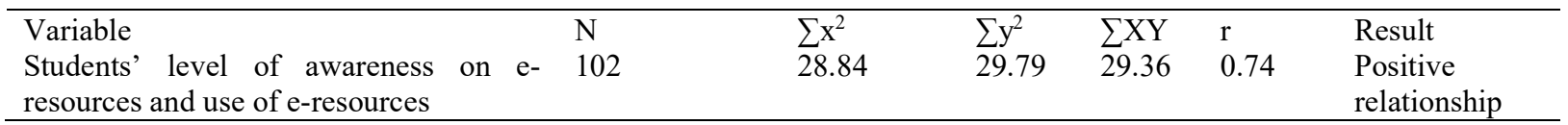

Correlated coefficient of 0.74 shows positive relationship between users' level of awareness and use of electronic information resources.

Research Question Three: What is the relationship between students' challenges in accessing and using electronic information resources?

Table 3: Correlation results indicating relationship between users' challenges in accessing and using electronic information resources.

\begin{tabular}{|c|c|c|c|c|c|c|}
\hline Variable & $\mathrm{N}$ & $\sum x^{2}$ & $\sum \mathrm{y}^{2}$ & $\sum X Y$ & $r$ & Result \\
\hline $\begin{array}{l}\text { Students'challenges in accessing of e- } \\
\text { resources, use of e-resources }\end{array}$ & 102 & 27.79 & 29.79 & 28.92 & 0.68 & $\begin{array}{l}\text { Positive } \\
\text { relationship }\end{array}$ \\
\hline
\end{tabular}

Calculated coefficient of 0.68 represents positive correlation between users' challenges in accessing and using electronic information resources. This result revealed positive relationship between understudied variables.

$\mathbf{H}_{0}$ 1: There is no significant relationship between students' accessibility and utilization of electronic information resources in University of Port Harcourt.

Table 4: Analysis of relationship between students' accessibility and utilization of electronic information resources.

\begin{tabular}{|c|c|c|c|c|c|c|c|c|c|}
\hline Variable & $\mathrm{N}$ & $r$ & r-crit & $\mathrm{df}$ & $\mathrm{P}$ & $z$-cal & $z$-crit & Resources & decision \\
\hline $\begin{array}{l}\text { Students' accessibility } \\
\text { of e-resources utilization } \\
\text { of e-resources }\end{array}$ & 102 & 0.87 & \pm 0.500 & 100 & 0.05 & 2.11 & 1.96 & Sig & Rejected \\
\hline
\end{tabular}

Table 4 null hypothesis test at 0.05 level of significance was rejected. This implies that the null hypothesis presenting r-value 0.87 and $z$-cal 2.11 greater than $r$-crit \pm 0.500 and $z$-crit 1.96 respectively clearly revealed that the subsisting relationship between students' accessibility and utilization of electronic information resources was significant. This shows that there is a significant relationship between the understudied variables. 
$\mathbf{H}_{0}$ 2: There is significant relationship between students' level of awareness and use of electronic information resources in University of Port Harcourt.

Table 5: Analysis of relationship between students' level of awareness and use of electronic information resources.

\begin{tabular}{|c|c|c|c|c|c|c|c|c|c|c|}
\hline Variable & & $\mathrm{N}$ & $\mathrm{r}$ & r-crit & $\mathrm{df}$ & $\mathrm{P}$ & $z$-cal & $z$-crit & Resources & decision \\
\hline $\begin{array}{l}\text { Students' } \\
\text { awareness } \\
\text { resources }\end{array}$ & $\begin{array}{l}\text { level of } \\
\text { use of e- }\end{array}$ & 102 & 0.74 & \pm 0.500 & 100 & 0.05 & 2.07 & 1.96 & Sig & Rejected \\
\hline
\end{tabular}

Table 5 null hypotheses test at 0.05 level of significance was rejected. This indicates that the null hypothesis presenting r-value $0.74 \mathrm{z}$-cal 2.07 greater than $\mathrm{r}$-crit \pm 0.500 and $z$-crit 1.96 respectively vividly revealed that the subsisting relationship between students' level of awareness and use of electronic information resources was significant. This reveals that there is significant relationship between the understudied variables.

$\mathbf{H}_{0}$ 3: There is no significant relationship between students' challenges in accessing and use of electronic information resources in University of Port Harcourt.

Table 6: Analysis of relationship between students' challenges in accessing and use of electronic information resources.

\begin{tabular}{|c|c|c|c|c|c|c|c|c|c|}
\hline Variable & $\mathrm{N}$ & $\mathrm{r}$ & r-crit & df & $\mathrm{P}$ & $z$-cal & $z$-crit & Resources & decision \\
\hline $\begin{array}{l}\text { Students' challenges in } \\
\text { accessing e-resources } \\
\text { use of e-resources }\end{array}$ & 102 & 0.68 & \pm 0.500 & 100 & 0.05 & 2.29 & 1.96 & Sig & Rejected \\
\hline
\end{tabular}

Table 6 null hypotheses test at 0.05 level of significance was rejected. This indicates that the null hypothesis presenting r-value 0.68 and $z$-cal 2.29 greater than $r$-crit \pm 0.500 and $z$-crit 1.96 respectively clearly revealed that the subsisting relationship between students' challenges in accessing and use of electronic information resources was significant. This affirms that there is a significant relationship between the understudied variables.

\subsection{Discussion of Findings \\ The relationship between students' accessibility and utilization of electronic information resources.}

The finding revealed a positive relationship between students' accessibility and utilization of electronic information resources. This implies that students can access information through websites with different search options, as well as accessing information from e-resources leading to effective utilization of e-resources geared towards the attainment of the university goals. The test of hypothesis one indicates that there is a significant relationship between students' accessibility and utilization of electronic information resources in University of Port Harcourt Library.

In line with the findings, Ogunsola (2011) argued that access to right information at the right time gives people greater control over their destiny. The scholar maintained that the ability to access electronic information resources enables a researcher to select the appropriate terminology that expresses the concept or subject under investigation. This is in agreement with the study of Al-Adwan et al (2013) who stated that although many universities across the world have incorporated internet-based learning systems, the success of their implementation requires an extensive understanding of end user acceptance process. The scholar asserts that:

The students requires knowing how to clearly define a subject or an area of investigation, formulate a search strategy that takes into consideration different sources of information and variables that information is organized, analyze the data collected for value, relevance and suitability. 
Students need to have the ability to access electronic information resources via search engines, subject gateways, web directories and other web-based resources. Adembo and Olatundum(2017) endorsed that strategies should be in place to improve access and use of e-resources as well as library orientation programmes.

\section{The relationship between students' level of awareness and use of electronic information resources.}

The findings equally reveals that a positive relationship exist between students' awareness and use of electronic information resources. This means that students' are aware of electronic information resources in the library but have challenges in accessing information as well as accessing up-to-date materials from e-resources. The test of hypothesis two shows that, there is a significant relationship between students' awareness and use of electronic information resources. This synchronizes with the findings of Shushma (2015) who argued that students lack skills in accessing e-resources; there should be an improvement in the access to facilities with high internet subscription to more e-resources in the university library. In the study of Boakye (2016) on the awareness, accessibility and utilization of e-resources, it revealed low awareness and accessibility as well as underutilization of e-resources. Ukachi(2014) affirmed that students should possess adequate information literacy skills on the use of electronic resources. However, availability of information does not assure its accessibility of information, the more accessible information resources, the more likely they are used. It is on this premise Keenan(2015) states that available experience are functions of creating audio, tutorials, collaborating with these students in the acquisition process and developing relevant accessibility services targeted to users' level of awareness and utilization of e-resources. Okoryo (2016) simply puts "the major challenge faced when accessing and utilizing electronic information as lack of awareness, training and poor infrastructure". Abubakar and Ahmed (2013) support this finding asserting that there is lack of awareness in developing countries especially with respect to e-resources services.

\section{The relationship between students' challenges in accessing and using electronic information resources.}

The findings went further to reveal that a positive relationship exist between students' challenges in accessing and using electronic information resources. This shows that students lack skills in accessing information, do not frequently use electronic resources, computers are not enough and do not know how to retrieve files easily. The test of hypothesis three indicates that there is significant relationship between students' challenges in accessing and using electronic information resources in University of Port Harcourt. In line with the findings, Jaegar (2007) posits that the various libraries need to assess users with different search tools to enable them access and retrieve information with ease. This means that users do not know how to access them and also do not know what the resources offer. Enite and Aworo (2015) affirmed that lack of search skills, inability to access and power outage are some of the challenges faced by staff in Nigerian libraries. This implies that for easy accessibility, students must have the ability to access electronic resources for the completion of their course work. This is why Okoryo (2016) argued that the major challenge faced when accessing and utilizing e-resources is lack of awareness, retrieval skills, enough computers and frequent use of e-resources which affects the achievement of covered institutional objectives.

\section{Conclusion}

Based on the findings, the researcher concluded that university libraries need to assist and guide students in accessing and utilizing the electronic information resources so as to improve their level of awareness in basic computer applications in order to cope with attendant challenges for the purpose of attaining predetermined organizational goals targeted to change the behavioural patterns of the learner. Librarian,s should do everything possible within their means to ensure that information resources are accessed and used by the students. This will help the students in their academics.

\section{Recommendations}

The researcher recommended that:

1. The librarians should help and assist students on how to access and utilize electronic information resources via tutorial, creating audio, collaborating with students in the acquisition process and developing relevant accessibility services.

2. The university management should train the students and provide more relevant electronic journals to ensure maximum access and use of scholarly electronic journals. University libraries should be 
appropriately funded thereby having up to date electronic information resources in the libraries to be accessed by students.

3. There should be a good internet network $24 / 7$

4. An electronic library should be made available at the medical library for the students to overcome the challenges of accessing and utilizing such electronic resources.

5. Librarian's should do advocacy on electronic resources inother to create awareness to student.

\section{References}

Abubakar, F.M. and Amed, H. B. (2013) The Moderating Effect Of Technology Awareness on the relationship Between UTAUT Construct and Behavioural Intention To Use Technology, A Conceptual Paper. Australian Journal of Business Management Research 3(2), 14-23.

Adebambo, A.O. Olatundum, O. (2017) Accessibility and Use of Web Based Electronic Resources by Physicians in a Psychiatric Institution in Nigeria. www.emeraldsight.com retrieved February, 2019.

Aina, R.F. (2011) Foundation of Information Studies, Lagos Emaphine Reprographics 47-48m 20-28.

Amos, E. (2012) The Use of Electronic Libraries. Journal of Academic Librarianship 2(1), 40-45.

Al-Adwan, A. and Medley, J. (2013) Exploring Students' Acceptance of E-Learning Using Technology Acceptance Model in Jordanian Universities. International Journal of Education and Development Using Information and Technology 9(2), 4-18.

Boakye, E.(2016) Accessibility and Utilization of Scholarly Electronic Journals by Academic Staff ofGarden City University College, Kumasi and Christian Service University College Kumasi, Ghana. Journal of New Review of Academic Librarianship 20(17), 30-42.

Habib, S. Enite, A. U. and Aworo, P. (2015) Accessibility and Utilization of Internet Services in Nigerian Libraries. International Journal of Academic Research and Reflection 3(8), 10-18.

Johnson, S. Evensen, O. G., Gelgand, J. Lammers, G. Siper, L and Zilps, N. (2012) Key Issues for E- Resources Collection Development: A Guide for Libraries. The Hage, Netherlands. IFLA.

Lefuma, S.(2017) Assessing Students' Utilization of Electronic Resources in Academic Libraries of Lesotho Library Consortium. Unpublished Thesis of University of Kwazulu-NatalPictemanbuig South-Africa. pp.101120.

Mohammed, S. (2013) The Relevance of Information to Libraries in Nigeria. Journal of Education 5(2), 33-39.

Ogunsola, L.A. Akindojutmi, B.F and Omoike, A.D (2011) Information Literacy of Nigeria. Higher Universities Any Role for Librarians. OzeanJournal of Social Sciences 4(2), 85-92.

Okonjo, A.N. (2016) Access and Utilization of Electronic Information Resources in University of Nariobi. An Unpublished Thesis pp.120-129.

Smith, B.J. (2016) Broadening Our Scope: International Collaboration for Retooling the Academic Library. Journal of Library Administration, 56(4) 395-415.

Sushma, N.J. (2015) Access, Awareness and Use of Electronic Resources by Post Graduate Students in Gulberga University International Journal of Information and Furistic Research 2(6) 19-30.

Ugah, A.D. (2008) Availability and Accessibility of Information Resourcesand the Use of Library Services in Michael Okpara University of Agriculture Retrieved February http://digital/common.un/edu/cgi/viewcontent.cgi 
Ukachi, N. (2014) Accessibility and Students' Variables as Correlates of the Use of Electronic Information Resources University Libraries is South-West, Nigeria. Research Journal of Library Information and Archival Studies 1(1) 001-007.

Uriel, U.O. (2016) Availability, Accessibility and Utilization of Library Information Resources by Students of Federal University of Technology Owerri. Journal of Information and Knowledge Management 6(10), 1-8.

Wu, A. Thompson, S. Vacek, R. Watkins, S. and Weidner, A. (2016) Hitting the Road From a Greater Digital Destination Evaluating and Testing Dams at University of Houston Libraries. Information Technologies and Libraries 35(2), 5.

\section{Boma T. David-West Ph.D, CLN}

\section{Biography}

I am Dr.(Mrs) Boma T. David-West . A lecturer in University of Port Harcourt, Department of Library and Information Science, Rivers State, Nigeria. A chartered librarian.B.A English HONS (2000) Masters in Library and Information Science (MLS) 2011 Ph.D in Library and Information Science 2019. My research interest is information use, cataloguing and classification, reference services, electronic resources, user's studies.

Phone: 08056048741

Email: boma.davidwest@uniport.edu.ng

\section{Patience O. EkpangPh.D, CLN}

I am Dr.(Mrs) Patience OwereEkang. Am a chartered librarian. I work with University of Calabar Library, Cross Rivers State, Nigeria.

My research interest is cataloguing, classification, reference services.

E-mail: ebanowere@gmail.com 